\title{
NOTES
}

\section{THE EXEMPTION STATUS OF THE BONA FIDE PLEDGEE OF UNREGISTERED SECURITIES UNDER THE SECURITIES ACT OF I933*}

“ $X$ Bank accepts as security for a substantial loan to Corporation $Y$ bonds issued by Corporation $Z$, controlled by $Y$. The loan, it is assumed, is made in good faith, with no purpose of effecting any distribution of the pledged bonds. The note or instrument of pledge contains a provision empowering $X$, in the event of default on the loan, to sell the pledged bonds privately or publicly for account of $Y$, applying the proceeds toward the payment of the loan and returning to $Y$ any sums remaining after the payment of the expenses of sale. A default occurring, $X$ desires to sell the bonds, and enters into negotiations with $B$, an investment banking house, for the sale of the bonds to it, $B$ proposing to organize a group of dealers to act as a selling group in the disposition of the bonds. Despite the default, $X$ is not in control of $Y$ and cannot compel registration of the bonds by $Z$. May $Z$, by its refusal to register, prevent disposition of the bonds by $X$ except in a non-public offering?"

With this example a former General Counsel of the Securities and Exchange Commission and his associate early illustrated a problem of interpretation which then lay latent in the term "underwriter," as used in the Securities Act of $1933{ }^{2}$ Is a bona fide pledgee who undertakes a

* This note was written during the summer of 1960 by a student who was then a law clerk in the Office of the General Counsel, Securities and Exchange Commission. The Commission, as a matter of policy, disclaims responsibility for any private publication by any of its employees. The views expressed herein are those of the author and do not necessarily reflect the views of the Commission or of the staft of the Commission.

${ }^{1}$ Throop \& Lane, Some Problems of Exemption Under the Securities Act of 1933,4 LaW \& Contemp. Prob. 89, 124 (1937). (Emphasis added.)

The Securities Act of 1933, 48 Stat. 74 (1933), as amended, 15 U.S.C. $\$ 77 a$ ( 1958 ), requires the disclosure of pertinent business and financial facts in connection with the public offering of securities so that investors will be provided with the means of reaching an informed judgment as to the investment merits of the security. Before an issue of securities may be offered to the public a registration statement must be filed with the SEC. Section 5, 15 U.S.C. $\$ 77 e$ (1958), is the statutory medium for restricting offerings to those made in accordance with the disclosure standards of the Act. Unless a registration statement has been filed with the Commission, it is illegal to offer to sell a security; unless a registration statement has becolne effective, it is illegal to sell or deliver a security. The prohibition of $\S 5$, by its terms, encompasses any offer, sale, or delivery after sale of a security.

Section $4(1)$, I5 U.S.C. $\$ 77 d(1)$ (1958), exempts certain transactions from the 
public sale of pledged securities an "underwriter," thereby subjecting the sale to the Act's registration requirements? This question, in substance though not in form, at last reached an appellate court; in May the Court of Appeals for the Second Circuit decided SEC v. Guild Films $\mathrm{Co}^{3}$

This case did not involve a bona fide pledge, where the lender takes securities as collateral to secure a loan which the debtor plans to pay at maturity and which the lender can reasonably expect will be retired. ${ }^{4}$ Still, this most important of the eleven circuit courts of appeals as far as securities law interpretation is concerned in effect held that "good faith" is irrelevant to the purpose of the statutory exemption, as the court has

registration requirements where, as the Congress stated, "... there is no practical need for ... [the bill's] application or where the benefits are too remote." H. REP. No. $S_{5}$, 73 d Cong., Ist Sess. (1933), p. 5, to accompany H.R. 5480, which became the Securities Act. The first clause of $\S_{4}(1)$ thus exempts "transactions by any person other than an issuer, underwriter, or dealer." "Underwriter" is broadly defined in $\S_{2}$ (II), I 5 U.S.C. $\$ 77 b$ (II) (1958), as follows:

The term "underwriter" means any person who has purchased from an issuer with a view to, or offers or sells for an issuer in connection with, the distribution of any security, or participates or has a direct or indirect participation in any such undertaking, or participates or has a participation in the direct or indirect underwriting of any such undertaking ....

${ }^{3} 279$ F.2d 485 (2d Cir. 1960), cert. denied, 29 U.S.L. Week 3099 (U.S. Oct. 11, 1960), affirming 178 F. Supp. 418 (S.D.N.Y. I959).

- In September r 958 Hal Roach, Jr., obtained a short term loan of $\$ 120,000$ from two California banks, depositing as collateral stock of a company of which he was a controlling stockholder. When this stock dropped in value as a result of having been suspended from trading on the New York Stock Exchange, the banks in December I958 demanded payment of the loan. Roach was in financial difficulty. For nearly two months the banks attempted unsuccessfully to obtain satisfaction of the loan before again demanding payment, this time by February 3. Then, two days before unregistered Guild Films stock was even issued to Roach, who represented to the company that the shares would be taken for investment and not for'distribution, Roach promised to deliver to the banks, purportedly as collateral, a certificate for 50,0oo shares. On the very day the certificate was received, the banks notified Roach that the Guild Films stock would be sold if the loan were not paid by February $I 6$, as the original securities were now valueless having also been barred from trading in the over-the-counter markets. This the banks undertook to do, until the SEC caused temporary restraining orders to issue.

Thus, the banks realized at the time they accepted the stock that whatever recovery they were to get would come from its distribution. The district court reached the "ultimate conclusion" that this "was not a pledge transaction at all" and that when the banks received the Guild Films stock from Roach they were "no longer looking for or hoping for payment from him." I78 F. Supp. 418, 423-24 (S.D.N.Y. 1959). The Court of Appeals itself stated that "the banks should have known that immediate sale was almost inevitable if they were to recoup their lonns from the security received." 279 F.2d ${ }_{4} S_{5}, 490$ (2d Cir. 1960). 
interpreted over the years the congressional mandate of disclosure to investors.

The Second Circuit divided when it first considered twenty years ago whether the statutory term "underwriter" should be interpreted broadly or narrowly. Leaving no room for misunderstanding, however, two of the three judges in SEC v. Chinese Consol. Benev. Ass $n^{5}$ limited the section $4(\mathrm{I})$ exemption to trading transactions between individual investors with relation to securities already issued; the court thus held that 4(I) was not intended to exempt distributions by issuers. Irrespective of whether one is an "underwriter," the exemption is unavailable to him if he engages, in violation of section 5 , in transactions in which an issuer is distributing securities. In Augustus Hand's plain language:

[Section 4(I)] does not in terms or by fair implication protect those who are engaged in steps necessary to the distribution of security issues, ${ }^{6}$

The breadth of the statutory policy of investor protection for which Chinese Consolidated thus stands, and conversely the narrowness of the 4(I) exemption, were reaffirmed without dissent in SEC v. Culpepper ${ }^{7}$ by a different panel of judges than were to sit one year later for $S E C$ v. Guild Films Co. In Culpepper the court restated its earlier holding that section 4(I) was not intended to exempt distributions by issuers, and extended it to "acts of other individuals who engage in steps necessary to such distributions, even if such individuals themselves do not come within the definition of 'issuer, underwriter, or dealer." "s The court then held that a broker who purchased from other brokers unregistered shares which he resold violated section 5 because he "consciously engaged in steps necessary to the consummation of the public distribution of shares by the issuer." He could not invoke the exemption provided by section $4(\mathrm{I})$.

When the SEC entered the District Court for the Southern Dis- trict of New York and obtained, after hearing, a preliminary injunction against the sale by two California banks of unregistered Guild Films

"120 F.2d 738 (2d Cir.), cert. denied, 314 U.S. 618 (1941).

${ }^{8}$ SEC v. Chinese Consol. Benev. Ass'n, suppra note 5 , at 741 .

${ }^{2} 270$ F.2d 241 (2d Cir. 1959). See also Gilligan, Will \& Co. v. SEC, 267 F.2d 46I (2d Cir. 1959), where this court held that resales of unregistered securitics by a firm that had acquired the securities ten months earlier with the intention to retain the securities only if the issuer continued to operate profitably rendered the firm an underwriter.

${ }^{8}$ SEC v. Culpepper, supra note 7 , at 247 . (Emphasis added.) 
Company stock, ${ }^{9}$ the applicability of the exemption to a pledgee's sale of collateral was ripe for judicial determination. ${ }^{10}$ On appeal Santa Monica Bank and the Southwest Bank of Inglewood contended that they were exempt from the registration requirements since they had acted in good faith and, as bona fide pledgees, were entitled on default to sell the collateral without registration. ${ }^{11}$ This assumption that "good faith" in accepting the stock was a sufficient defense was repudiated by the court:

${ }_{178}$ F. Supp. 418 (S.D.N.Y. 1959). It is noteworthy that this proceeding, before Sylvester J. Ryan, U.S.D.J., involved a hearing of some two and a half days length. Preliminary injunctions in the ordinary case issue upon the mere filing of affidavits.

${ }^{10} \mathrm{Up}$ to this point the uncertain status of the bona fide pledgee under the Securities Act aroused little concern since private interests had been unaffected. Legislative history records that the Securities Act, as proposed to Congress and as originally passed by the Senate, expressly exempted sales in liquidation by a pledgee of securities taken in good faith as collateral for a bona fide debt. This exemption was subsequently eliminated from the Act as passed, which alone suggests a legislative intent to require registration. A more encompassing analysis, however, apparently contributed much to an early understanding to the contrary. Throop \& Lane, supra note 1 , at 124 n. 103. See Loss, SeCURITIES Regulation 333 n. 99 (195 I). Although admitting that the definition of the term "underwriter," if torn from its context, is broad enough to include the pledgee who, although not in a position to compel registration, finds it necessary in the collection of his debt-to utilize the usual channels of distribution, Throop and Lane wrote at 124 that its consideration "from a functional point of view would without doubt lead a court to conclude that a bona fide pledgee in such a situation is not to be regarded as an underwriter." The viewpoint of these two former General Counsels of the Commission was thoroughly considered on oral argument to the court.

Appellants also cited the Court of Appeals to Loss, SEcuritifs Regulation at 333. Brief for Appellants, p. 8. There, Loss states that a bona fide gift is not a sale and that "the Commission has taken the same position with respect to pledges and loans of securities." The footnote reference thereto refers only to loans. The Court of Appeals, however, noted Loss's own opinion on page 346. 279 F.2d 485, 490 (2d Cir. 1960). Here, he states that "it would hardly be logical to consider [a pledgee who takes securities from the issuer as collateral for a loan] to be an underwriter unless the entire pledge arrangement was a subterfuge."

${ }^{11}$ Brief for Appellants, pp. 7-15. Appellant banks also contended that they did not "purchase" within the meaning of $\S_{2}$ (II). See note 2 supra. The court held, however, that although the term is not defined in the Act, it should be interpreted in a manner complementary to "sale" which is defined in $\S_{2}(3)$ as including "every ... disposition of .... a security or interest in a security, for value ...."

The contention that the banks did not deal directly with the issuer, Guild Films Company, was in turn rejected, for the Second Circuit had recently stated that "the underlying policy of the Act, that of protecting the investing public through the disclosure of adequate information, would be seriously impaired if . . . a dealer must have conventional or contractual privity with the issuer in order to be an 'underwriter'." SEC v. Culpepper, 270 F.2d 241, 246 (2d Cir. 1959), following SEC v. Chinese Consol. Benev. Ass'n, I20 F.2d 738 (2d Cir. 194I). 
[T] he statute does not impose such a "good faith" criterion. The exemption in $\$ 4(\mathrm{I})$ was intended to permit private sales of unregistered securities to investors who are likely to have, or who are likely to obtain, such information as is ordinarily disclosed in registration statements .... The "good faith" of the banks is irrelevant to this purpose. It would be of little solace to purchasers of worthless stock to learn that the sellers had acted "in good faith." Regardless of good faith, the banks engaged in steps necessary to this public sale, and cannot be exempted. ${ }^{12}$

Registration is required, therefore, where the securities to be sold are transferred by a debtor who would otherwise be required to effect registration and taken by a creditor with the specific intention that they be distributed in order to obtain repayment of the loan. Registration may even be required in the ordinary collateral situation, where disclosure is in the interest of the public and for the protection of investors. Regardless of the "good faith" of the creditor, if he is a participant in a public offering, he is an "underwriter" within the statutory definition of that term. The intervention of a pledge transaction, even if bona fide, does not absolve those upon whom Congress has imposed the duty of disclosure.

In the light of this development of the law, to return to the initially stated example, could the $X$ Bank be prevented from publicly disposing of the $Z$ bonds which it holds as collateral for a loan by Corporation $Y$, which is in default, if Corporation $Z$ refuses to register? It is unquestioned that neither the issuer, Corporation $Z$, nor one in control of the issuer, Corporation $Y$, could lawfully dispose of the bonds, except in a nonpublic offering, absent their effective registration. The intervention of the $X$ Bank in the distribution process apparently offers no basis for a different statutory consequence. Regardless of its "good faith," $X$ Bank would be a participant in a public offering and hence an "underwriter." $Z$ 's refusal to register the bonds necessarily limits $X$ Bank, which is technically and economically prohibited from effecting registration itself, to nonpublic attempts at disposition.

Apparently, the only recourse a lending institution has where the borrower offering unregistered securities as collateral is the issuer, a person in control of the issuer ( $Y$ Corporation), or a person who bought from either of them, ${ }^{13}$ is to insist on registration at the time of making

\footnotetext{
${ }^{10} 279$ F.2d 485,490 (2d Cir. 1960).

${ }^{13}$ If the borrower is neither the issuing corporation nor a person having any relation to the issuer, no problem of registration is involved.
} 
the loan ${ }^{14}$ or to require a commitment that, upon default, registration will then be effected. ${ }^{15}$ The implications of extending the rigidities of the registration process to this aspect of corporation finance, however, will require careful study by the SEC before a program of enforcement is seriously undertaken. The nature and purpose of these loans, which are generally secured by the issues of subsidiaries pledged to finance the acquisition of new subsidiaries, the credit prospects for small businesses for whom registration may not be feasible, and the potential loss to the banking community of legitimate, though marginal, banking. business, are weighty considerations.

Certainly in principle this broad, expansive view of the Securities Act registration requirement, taken by a court that could not have been unmindful of its practical implications, should be sustained. In rendering the criterion of "good faith" irrelevant, the court corrected any misconception that the Securities Act was designed to impose penalties on male fides. Registration is not, after all, a penalty. It is simply the means adopted "to protect investors by promoting full disclosure of information ... necessary to informed investment decisions."16 Thus, the SEC's interpretation of the Act's demands, which has again found favor with the Second Circuit, is understandable:

The congressional mandate of disclosure to investors is not to be set aside to permit a public distribution of non-registered securities because a creditor desires to collect a loan by selling collateral. There is no warrant for subordinating the public interest to this private interest, whether or not the creditor acted in good faith. ${ }^{17}$

\footnotetext{
${ }^{14}$ Throop \& Lane, supra note II.

${ }^{15}$ Brief for SEC in opposition to petition for writ of certiorari, p. 7 n. 6.

${ }^{10}$ SEC v. Ralston Purina Co., 346 U.S. I I9, 124 (1953).

${ }^{27}$ Brief for SEC in opposition to petition for writ of certiorari, pp. 6-7.
} 